\title{
Construction of Knowledge Test to Measure the Knowledge of Famers on Recommended Tomato Cultivation Practices
}

\author{
K. Madhuri*, V. Sailaja and P.V. Sathya Gopal \\ Acharya N G Ranga Agricultural University, Department of Agricultural Extension, \\ S. V. Agricultural College, Tirupathi-517502, India
}

*Corresponding author

\section{A B S T R A C T}

\begin{tabular}{|l|}
\hline Ke y w o r d s \\
Knowledge test, \\
Tomato farmers, \\
Recommended \\
practices, Tomato, \\
Andhra Pradesh \\
\hline Article Info \\
\hline $\begin{array}{l}\text { Accepted: } \\
\text { 10 June } 2019 \\
\text { Available Online: } \\
\text { 10 July } 2019\end{array}$ \\
\hline
\end{tabular}

\section{Introduction}

In the present study, knowledge was operationalized as the extent of information known or possessed by the tomato farmers on recommended tomato production package of practices. A knowledge test was developed with thirty six (36) items to measure the knowledge of unreached farmers on recommended practices. Each item was measured on two point continuum viz., correct and incorrect with ' 1 ' and ' 0 ' score respectively. The possible maximum and minimum scores to be obtained by unreached farmers were 36 and 0 respectively. The detailed procedure followed for the construction and standardization of the knowledge test is shown below.

\section{Materials and Methods}

\section{Collection of items}

The content of the test was composed of questions called items. A comprehensive list (65) of knowledge questions on recommended production technology with special emphasis on recommended cultivation practices of 
tomato was prepared on the basis of extensive review of literature, consultation with scientists of ANGRAU and Extension officers of State Department of Horticulture of Andhra Pradesh.

\section{Selection of items}

The selection of items was done on the basis of the following criteria.

Response to items should promote thinking than routine memorization

They should differentiate the well informed respondent from less informed and should have certain difficulty value. The items included should cover all areas of knowledge about production technology.

\section{Form of questions}

The items selected for the construction of knowledge test on production technology with special emphasis on recommended cultivation practices of tomato crop were framed in the objective form of questions namely multiple choice, fill in the blanks, yes or no and true or false.

\section{Pre-testing}

The items selected for the knowledge test were pre-tested separately by administering the items to 60 respondents. Care was taken to see that 60 respondents selected for this purpose were outside the main sample of this study.

\section{Item analysis}

The Item analysis was carried out to yield two kinds of information viz., indices of 'Item difficulty' and 'Item discrimination'. The index of item difficulty indicates the extent to which an item was difficult. The later provides information on how well an item measures or discriminates a well - informed respondent from poorly informed respondent. To analyse the items undertaken for item analysis, each response for multiple choice, fill in the blanks, true or false and yes or no, questions were given a score of one and zero for correct and incorrect responses, respectively. After computing the individual total score for the 60 respondents, the respondents were arranged in descending order based on total score.

These 60 respondents were then divided into 6 equal groups named as G1, G2, G3, G4, G5, and G6 with 10 respondents in each group. For item analysis, the middle two groups G3 and G4 were eliminated keeping only 4 extreme groups, with high scores namely, Gl and G2 and low scores namely, G5 and G6. After getting the four extreme groups for item analysis, the responses for each of the items were subjected to calculate difficulty index, discrimination index and point biserial correction as shown below.

\section{Item difficulty index}

The item difficulty index of each of the items, that is, the percentage of respondents answering an item correctly was computed by using the following formula

Item difficulty index $(\mathrm{P})=$ $\frac{\text { No. of respondens answeredcorrectly }}{\text { Totalno.of responden } \$} \times 100$

The items with difficulty index ranging from 20 to 80 were considered for final selection for the knowledge test to avoid extremely simple and difficult items.

\section{Discrimination index}

Discrimination index of each of the items were computed by using the following formula. 
$\mathrm{E} 1 / 3=\frac{(\mathrm{S} 1+\mathrm{S} 2)-(\mathrm{S} 5+\mathrm{S} 6)}{\mathrm{N} / 3}$

Where, SI, S2, S5 and S6 are the frequencies of correct answers in groups GI, G2, G5 and G6, respectively and $\mathrm{N}=$ Total number of respondents in the sample selected for items analysis (60). The value of the discrimination index for the knowledge items on production technology with special emphasis on recommended cultivation practices of tomato crop were presented in Appendix III.

The items with E1/3 value ranging from 0.2 to 0.8 were considering for the final selection of knowledge test for same reasons explained under item difficulty index (Table 1).

\section{Point biserial correlation}

Point biserial correlation (rpbis) is the test validation in which the criterion of validity is considered to be internally consistent. That is, the relationship of the total score to a dichotomized response to any given item. An item by item computation of point biserial correlation was calculated by using the formula.

rpbis $=\frac{\mathrm{MP}-\mathrm{MQ}}{\mathrm{S} . \mathrm{D} .} \times \sqrt{\mathrm{pq}}$

Where,

rpbis $=$ Point biserial correlation

MP $=$ Mean of the scores of the respondents who answered the item correctly (or)

$\mathrm{Mp}=\frac{\text { Sum of the total of } \mathrm{XY}}{\text { Total number of correct answers. }}$

$\mathrm{Mq}=$ Mean of the total scores of the respondents who answered the item incorrectly
$\mathrm{Mq}=\frac{\text { Sum total of } X-\text { Sum total of } X Y}{\text { Totalnumber of wrong answers }}$

$\mathrm{SD}=$ Standard deviation of the entire sample

$\mathrm{p}=$ Proportion of the respondents giving correct answer to the item

$\mathrm{q}=$ Proportion of the respondents giving incorrect answer to the item (or) $q=1-p$

$X=$ Total score of the respondent for all the items

$\mathrm{Y}=$ Response of the individual for the items (Correct $=1$; Incorrect $=0$ )

$\mathrm{XY}=$ Total score of the respondent multiplied by the response of the individual item.

Items having significant point biserial correlation, either at 1 per cent or 5 per cent level were selected for the final test of the knowledge.

\section{Selection of the items}

Out of 65 items 36 items were finally selected based on the following criteria.

Items with difficulty level indices ranging from 20 to 80 .

Items with discrimination indices ranging from 0.20 to 0.80 .

Items having point biserial correlation either at 1 per cent or 5 per cent level

Thus the finally selected 36 knowledge test items comprised of four types of questions viz.,

Multiple choice, Fill in the blanks, Yes or, True or False and Question and answer are furnished in table 2 . 
Int.J.Curr.Microbiol.App.Sci (2019) 8(7): 888-895

Table.1 Respondents in four extreme groups

\begin{tabular}{|c|c|c|c|c|c|c|c|}
\hline \multirow{2}{*}{ 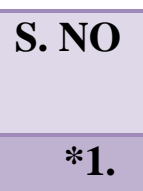 } & \multicolumn{4}{|c|}{$\begin{array}{l}\text { Frequencies of correct answers in } \\
\text { four extreme groups }\end{array}$} & \multirow{2}{*}{$\begin{array}{c}\text { Difficulty } \\
\text { index } \\
\\
\quad 78.00\end{array}$} & \multirow{2}{*}{$\begin{array}{c}\text { Discrimination } \\
\text { index } \\
0.3\end{array}$} & \multirow{2}{*}{$\begin{array}{l}\text { rpbis } \\
0.3617\end{array}$} \\
\hline & 8 & 8 & 4 & 4 & & & \\
\hline 2. & 8 & 10 & 4 & 4 & 78.00 & 0.05 & 0.269 \\
\hline$* 3$ & 8 & 4 & 0 & 0 & 45.00 & 0.2 & 0.013 \\
\hline$* 4$ & 10 & 4 & 8 & 2 & 47.00 & 0.5 & 0.3348 \\
\hline$* 5$ & 10 & 10 & 6 & 4 & 77.00 & 0.5 & 0.4817 \\
\hline$* 6$ & 10 & 10 & 10 & 10 & 68.00 & 0.4 & 0.4083 \\
\hline$* 7$ & 10 & 10 & 6 & 4 & 78.00 & 0.2 & 0.4190 \\
\hline$* 8$. & 10 & 6 & 8 & 6 & 75.00 & 0.5 & 0.4116 \\
\hline 9. & 10 & 10 & 10 & 10 & 90.00 & 0.05 & 0.4083 \\
\hline$* 10$. & 8 & 8 & 4 & 2 & 43.00 & 0.2 & 0.3683 \\
\hline 11. & 10 & 10 & 10 & 10 & 96.00 & 0.1 & 0.4116 \\
\hline$* 12$. & 10 & 10 & 6 & 6 & 86.00 & 0.4 & 0.4083 \\
\hline 13. & 10 & 10 & 4 & 4 & 72.00 & 0.05 & 0.3683 \\
\hline 14. & 10 & 10 & 10 & 10 & 90.00 & 0.1 & 0.4116 \\
\hline 15. & 10 & 6 & 10 & 6 & 76.00 & 0.2 & 0.4190 \\
\hline$* 16$. & 8 & 8 & 4 & 4 & 50.00 & 0.5 & 0.3617 \\
\hline 17. & 10 & 10 & 10 & 10 & 100.00 & 0.00 & 0.4385 \\
\hline 18. & 10 & 4 & 8 & 2 & 88.00 & 0.00 & 0.4190 \\
\hline$* 19$. & 10 & 10 & 10 & 6 & 80.00 & 0.4 & 0.1960 \\
\hline 20. & 10 & 10 & 10 & 8 & 88.00 & 0.4 & 0.087 \\
\hline$* 21$. & 10 & 10 & 10 & 6 & 77.00 & 0.4 & 0.4190 \\
\hline$* 22$. & 4 & 2 & 1 & 4 & 43.00 & 0.2 & 0.338 \\
\hline 23. & 10 & 8 & 6 & 8 & 88.00 & 0.3 & 0.4885 \\
\hline 24. & 10 & 10 & 10 & 10 & 100.00 & 0.1 & 0.1960 \\
\hline 25. & 2 & 4 & 2 & 2 & 22.00 & 0.00 & 0.3645 \\
\hline$* 26$. & 10 & 10 & 4 & 6 & 70.00 & 0.5 & 0.413 \\
\hline$* 27$. & 10 & 4 & 8 & 2 & 39.00 & 0.3 & 0.2908 \\
\hline 28. & 8 & 6 & 0 & 2 & 87.00 & 0.4 & 0.3683 \\
\hline 29. & 10 & 10 & 10 & 10 & 88.00 & 0.4 & 0.3761 \\
\hline$* 30$ & 10 & 10 & 10 & 6 & 48.00 & 0.2 & 0.2033 \\
\hline$* 31$ & 8 & 8 & 0 & 2 & 68.00 & 0.4 & 0.4990 \\
\hline
\end{tabular}




\begin{tabular}{|c|c|c|c|c|c|c|c|}
\hline *32. & 6 & 6 & 2 & 2 & 33.00 & 0.2 & 0.164 \\
\hline 33. & 2 & 4 & 2 & 2 & 10.00 & 0.3 & 0.3645 \\
\hline 34. & 6 & 6 & 2 & 2 & 40.00 & 0.05 & 0.1960 \\
\hline$* 35$. & 10 & 4 & 6 & 6 & 10.00 & 0.4 & 0.231 \\
\hline 36. & 10 & 8 & 10 & 6 & 96.00 & 0.2 & 0.2908 \\
\hline 37. & 10 & 10 & 10 & 6 & 82.00 & 0.3 & 0.3645 \\
\hline 38. & 10 & 8 & 6 & 1 & 73.00 & 0.05 & 0.167 \\
\hline 39. & 2 & 4 & 2 & 2 & 16.00 & 0.1 & 0.013 \\
\hline$* 40$. & 10 & 6 & 8 & 6 & 73.00 & 0.2 & 0.2159 \\
\hline$* 41$. & 10 & 10 & 8 & 10 & 78.00 & 0.3 & 0.3288 \\
\hline$* 42$. & 4 & 2 & 4 & 2 & 42.00 & 0.3 & 0.404 \\
\hline$* 43$. & 10 & 10 & 4 & 6 & 70.00 & 0.5 & 0.552 \\
\hline$* 44$. & 10 & 10 & 6 & 4 & 70.00 & 0.4 & 0.317 \\
\hline$* 45$. & 10 & 10 & 6 & 2 & 65.00 & 0.2 & 0.362 \\
\hline$* 46$. & 10 & 6 & 8 & 6 & 73.00 & 0.3 & 0.3288 \\
\hline$* 47$. & 8 & 8 & 4 & 4 & 67.00 & 0.3 & 0.5459 \\
\hline$* 48$. & 8 & 10 & 4 & 2 & 75.00 & 0.5 & 0.5431 \\
\hline$* 49$. & 10 & 10 & 6 & 4 & 79.00 & 0.5 & 0.621 \\
\hline 50. & 10 & 6 & 8 & 6 & 82.00 & 0.2 & 0.1960 \\
\hline 51. & 10 & 4 & 6 & 6 & 83.00 & 0.3 & 0.3012 \\
\hline$* 52$. & 8 & 8 & 4 & 4 & 57.00 & 0.2 & 0.1960 \\
\hline 53. & 10 & 10 & 6 & 6 & 88.00 & 0.02 & 0.013 \\
\hline$* 54$. & 4 & 2 & 1 & 4 & 35.00 & 0.3 & 0.318 \\
\hline$* 55$. & 10 & 6 & 8 & 6 & 73.00 & 0.4 & 0.410 \\
\hline 56. & 10 & 10 & 10 & 10 & 95.00 & 0.1 & 0.439 \\
\hline$* 57$. & 8 & 10 & 10 & 6 & 76.00 & 0.4 & 0.4817 \\
\hline 58. & 10 & 10 & 10 & 10 & 100.00 & 0.0 & 0.100 \\
\hline *59. & 10 & 8 & 8 & 4 & 77.00 & 0.5 & 0.329 \\
\hline$* 60$. & 10 & 10 & 10 & 10 & 80.00 & 0.6 & 0.693 \\
\hline 61. & 2 & 1 & 2 & 4 & 13.00 & 0.3 & 0.207 \\
\hline 62. & 8 & 8 & 4 & 4 & 67.00 & 0.4 & 0.362 \\
\hline *63. & 10 & 6 & 8 & 6 & 70.00 & 0.3 & 0.552 \\
\hline 64. & 2 & 4 & 2 & 2 & 23.00 & 0.4 & 0.231 \\
\hline 65. & 6 & 8 & 10 & 4 & 63.00 & 0.3 & 0.207 \\
\hline
\end{tabular}


Table. 2 Knowledge items identified for tomato crop

\begin{tabular}{|c|c|c|}
\hline $\begin{array}{l}\text { Sl. } \\
\text { NO }\end{array}$ & $\begin{array}{l}\text { Selected } \\
\text { questions }\end{array}$ & Knowledge items for tomato \\
\hline 1 & $1 *$ & $\begin{array}{l}\text { The best suited soils for the tomato cultivation is } \\
\text { (a)Sandy loams (b) Rich loamy soils (c) Silt loams }\end{array}$ \\
\hline 2 & $3 *$ & $\begin{array}{l}\text { The summer tomato crop (improved variety) requires a seed rate of } \\
\text { (a) } 200 \mathrm{~g} \text { (b) } 400 \mathrm{~g} \text { (c) } 500 \mathrm{~g}\end{array}$ \\
\hline 3 & $4^{*}$ & $\begin{array}{l}\text { The optimum seed rate recommended for hybrid tomato per one ha is } \\
\text { (a) } 75 \mathrm{~g} \text { (b) } 100 \mathrm{~g} \text { (c) } 150 \mathrm{~g}\end{array}$ \\
\hline 4 & $5^{*}$ & $\begin{array}{l}\text { Optimum plant spacing to be followed in tomato in summer season is } \\
\text { (a) } 45 \times 45 \mathrm{cms} \text { (b) } 60 \times 45 \mathrm{cms} \text { (c) } 75 \times 60 \mathrm{cms}\end{array}$ \\
\hline 5 & $6^{*}$ & $\begin{array}{l}\text { The quantity of FYM / compost recommended for one ha of tomato } \\
\text { crop } \\
\text { (a)5-4 tons (b) 6-8 tons (c) } 10 \text { tons }\end{array}$ \\
\hline 6 & $7 *$ & 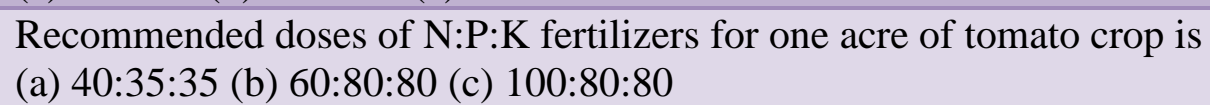 \\
\hline 7 & $8^{*}$ & $\begin{array}{l}\text { Number of hybrid tomato plants per hill is/are allowed to get good } \\
\text { yield } \\
\text { (a) One plants (b) Two plants (c) Three Plants }\end{array}$ \\
\hline 8 & $10^{*}$ & $\begin{array}{l}\text { The control of flower and fruit drop in tomato is by using } \\
\text { (a)2,4-D (b) Cycocel (c) } 1 \% \text { urea spray }\end{array}$ \\
\hline 9 & $12 *$ & 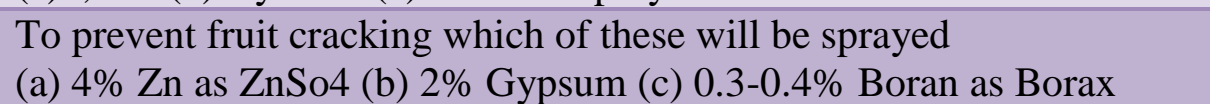 \\
\hline 10 & $16^{*}$ & $\begin{array}{l}\text { For long distance transportation, the tomatoes are harvested when they } \\
\text { are } \\
\text { (a) Firm mature and nearly red (b) Firm immature and greenish yellow } \\
\text { (c)Firm mature and greenish yellow }\end{array}$ \\
\hline 11 & $19 *$ & $\begin{array}{l}\text { Ideal trap crop for tomato fruit borer } \\
\text { (a) Mustard (b) Tobacco (c) Marigold }\end{array}$ \\
\hline 12 & $21 *$ & $\begin{array}{l}\text { Do you feel that tomato can be successfully grown in regions of higher } \\
\text { rainfall areas? Yes/No }\end{array}$ \\
\hline 13 & $22 *$ & $\begin{array}{l}\text { Do you observe that proper weeding in the early stages is determinant } \\
\text { to crop growth? Yes/No }\end{array}$ \\
\hline 14 & $26^{*}$ & $\begin{array}{l}\text { Does seed treatment with fungicide reduces the disease occurrence in } \\
\text { initial stages of crop growth? Yes/No }\end{array}$ \\
\hline 15 & $27 *$ & Does optimum spacing helps to get good yield? Yes/No \\
\hline 16 & $30 *$ & Does winter season is suitable to get higher yields? Yes/No \\
\hline 17 & $31 *$ & Tomato is rich in vitamin "C" True/false \\
\hline 18 & $32 *$ & Tomato can be cultivated in all seasons in South India. True/False \\
\hline 19 & $35^{*}$ & Seedbeds should be raised 6 inches above the ground level True/False \\
\hline 20 & $40 *$ & $\begin{array}{l}\text { Harvesting of tomato fruits is to be done in the cooler periods of the } \\
\text { day True/False }\end{array}$ \\
\hline 21 & $41^{*}$ & $\begin{array}{l}\text { Staking is preferred for the development of good size quality fruits } \\
\text { True/False }\end{array}$ \\
\hline
\end{tabular}




\begin{tabular}{|c|c|c|}
\hline 22 & $42 *$ & The improved variety of tomato recommended to your area is--------- \\
\hline 23 & $43^{*}$ & The improved Hybrid of tomato recommended to your area is---------- \\
\hline 24 & $44 *$ & The chemical used for seed treatment in tomato is------------ \\
\hline 25 & $45^{*}$ & The herbicide commonly used for weed control in tomato crop is------ \\
\hline 26 & $46^{*}$ & Major pest that occurs in tomato crop is----------- \\
\hline 27 & $47 *$ & The common disease that occurs in the nursery of tomato is-------- \\
\hline 28 & $48 *$ & The seedlings of-------------cms height are best for transplanting \\
\hline 29 & $49 *$ & The seedlings of---------weeks old are transplanted in the main field \\
\hline 30 & $52 *$ & The duration of the tomato crop is----------- \\
\hline 31 & $54 *$ & Tomato leaf curl virus is transmitted by---------- \\
\hline 32 & $55^{*}$ & $\begin{array}{l}\text { What is the insecticide and its recommended dosage to control } \\
\text { Helicoverpa? }\end{array}$ \\
\hline 33 & $57^{*}$ & What are the benefits of staking in tomato cultivation? \\
\hline 34 & $59 *$ & $\begin{array}{l}\text { Did you notice any leaf miner damage in your crop if so what is the } \\
\text { percent damage and yield loss? }\end{array}$ \\
\hline 35 & $60^{*}$ & Is seed treatment with bioagents (Trichoderma etc.) is beneficial? \\
\hline 36 & $63^{*}$ & What is the row proportion of trap crop and main crop? \\
\hline
\end{tabular}

\section{Reliability of the test}

Split half method was used to compute the reliability of the test. The test administered to 60 respondents was divided into two halves based on odd and even numbered items. Two sets of scores were derived on half forms of the test and the scores were correlated for the reliability of the half test.

The self-correlation of the whole test was then estimated by the Spearman Brown prophecy Formula. The calculated value of reliability Co-efficient (0.78) for whole test found to be highly significant, hence it was concluded that test was reliable.

\section{Validity of the test}

Knowledge test developed on recommended cultivation practices in tomato cultivation was subjected to content and construct validity. The construct validity of the test items was tested by the method of point biserial correlation ( $\mathrm{r}$ pbis). The items have significant values at 1 per cent and 5 per cent level indicated the validity of the test.
The content validity of knowledge test was derived from a large pool of test items separately. The test items represented the whole universe of cultivation practices of tomato crop.

It was thus assumed that the scores obtained by administering the knowledge test of this study measures what intended to measure.

Thus the knowledge test developed in the present study can measure the knowledge of the farmers on cultivation practices of tomato crop and showed a greater degree of reliability and validity indicating that the test items were valid.

\section{Administration of the test}

Each item was read out to the respondents by the investigator and response was recorded with a score of one for correct answer and zero for wrong answer.

The possible maximum and minimum possible score that an individual respondent would get were 36 and 0 respectively. 


\section{Results and Discussion}

Table 2 represents the final knowledge items selected for assessing the knowledge level of farmers on recommended crop production package of practices on tomato. The scale standardized may be directly used by a researcher for assessing knowledge level of farmers on recommended groundnut production of practices. The items selected finally using standard procedures includes different aspects of crop production and different form of questions viz., multiple choice questions, yes or no type questions, true or false and fill up the blanks and direct one word answer.

The scale constructed following standard procedures may be used by the researchers for similar studies. The scale constructed will save the time of researchers working on similar lines.

\section{References}

Archana, P., Jagan Mohan Reddy, M., Sreenivasa Rao, I and Vidya Sagar, G.E.Ch. 2017. Construction of Knowledge Test to Measure the Knowledge of Watershed Farmers towards Natural Resource Management Practices. Int.J.Curr.Microbiol.App.Sci. 6(9): 81-89.

Berjesh, A and Ajay, K. 2009. Knowledge of farmers about soil and rainwater conservation technology and its determinants. Agriculture Science Digest. 29(4): 283-286.
Kadam, R.P., Wangikar, S. D., Pawar, G. S and Bhosale, P.B. 2005. Knowledge level of farmers about improved soybean production technologies. Journal of soil and crops. 15(1): 210212.

Latha, S. M. 2002. A study on knowledge and adoption of integrated pest management practices in cotton by farmers in Kurnool district of Andhra Pradesh. M.Sc. (Ag.) Thesis. Acharya N.G. Ranga Agricultural University, Hyderabad, India.

Rajendhra kumar 2002 Astudy on knowledge and adoption of recommended practices of hybrid jowar seed production in Kurnool district of Andhra Pradesh. M.Sc. (Ag.) Thesis, Acharya N. G. Ranga Agricultural University, Hyderabad, India.

Ramu, A. G. 2005. Knowledge and adoption of Turmeric farmers in Kadapa distirict of Andhra Pradesh. M.Sc. (Ag.) Thesis. Acharya N.G. Ranga Agricultural University, Hyderabad, India.

Sarkar, S., Padaria, R.N., Vijyaragavan, K., Pathak, H., Bhowmik, A., Kumar, P and Jha, G.K. 2014. Constructing a knowledge level of farmers about climate change in arid india. International journal of Bio-resource and Stress management. 5(4): 530-535.

Subhadeeproy and Rekha. 2012. Level of knowledge and extent of doption of farmers on recommended tuberose production practices. Indian Journal of Extension Education. 48 (1\&2): 78-80.

\section{How to cite this article:}

Madhuri, K., V. Sailaja and Sathya Gopal, P.V. 2019. Construction of Knowledge Test to Measure the Knowledge of Famers on Recommended Tomato Cultivation Practices. Int.J.Curr.Microbiol.App.Sci. 8(07): 888-895. doi: https://doi.org/10.20546/ijcmas.2019.807.106 